\title{
Implementasi Iman Kristen Dalam Masyarakat: Analisis Wacana Film God's Not Dead
}

\author{
Yuangga Kurnia Yahya \\ Universitas Darussalam Gontor \\ Yuangga4@unida.gontor.ac.id
}

DOI: https://doi.org/10.34307/b.v3i2.15

\begin{abstract}
This article discuss the religious realities that revealed in Trilogy of the film God 's Not Dead (2014), God' s Not Dead 2 (2016), and God 's Not Dead: A Light in Darkness (2018). This article is the result of a qualitative study using the Van Dijk's discourse analysis approach. Discourse in movie is not enough to rely on the text simply because it consists of various structures and levels. The structure is macro structure, super structure, and micro structure. In the results of the study it was found that the preparation of discourse was quite structured, ranging from thematic structures, schematic structures, semantic structures, syntactic structures, stilistic structures, and rhetorical structures. Macro structure includes thematic structures, super structures include schematic structures, while the rest are included in the microstructure. The two elements of the structure show that this film does convey a real message that God still has a place in human life even though it lives in a very rational environment and does not involve God in their lives.
\end{abstract}

Keywords: Theism, Christian Faith, Secularism, Film, Discourse Analysis.

Abstrak: Artikel ini membahas tentang realitas keagamaan yang tampak dalam Trilogi film God's Not Dead (2014), God's Not Dead 2 (2016), dan God's Not Dead: A Light in Darkness (2018). Artikel ini merupakan hasil dari studi kualitatif menggunakan pendekatan analisis wacana model Teun A Van Dijk. Wacana dalam film tidak cukup disandarkan pada teks semata karena ia terdiri dari berbagai struktur dan tingkatan. Struktur tersebut adalah struktur makro, super struktur, dan struktur mikro. Dari hasil penelitian ditemukan bahwa penyusunan wacana cukup terstruktur, mulai dari struktur Tematik, Struktur Skematik, Struktur Semantik, Struktur Sintaksis, Struktur Stilistik, dan struktur retorisnya. Struktur Makro meliputi struktur tematik, super struktur meliputi struktur skematik, adapun sisanya termasuk dalam struktur mikro. Kedua unsur dari struktur tersebut menunjukkan bahwa film ini memang menyampaikan pesan nyata bahwa Tuhan tetap memiliki tempat di kehidupan manusia meskipun hidup di lingkungan yang sangat rasional dan tidak melibatkan Tuhan dalam kehidupan mereka.

Kata Kunci: Teisme, Iman Kristen, Film, Analisis Wacana.

\begin{tabular}{llll}
\hline Article History : & Received: 06-04-2020 Revised: 11-12-2020 Accepted:13-12-2020
\end{tabular}




\section{Pendahuluan}

Film menjadi salah satu media komunikasi massa di zaman. Di era digital ini, film dan tayangan televisi lainnya merupakan media dalam penyampaian pesan kepada masyarakat. Dalam waktu singkat, pesan yang disampaikan dapat segera tersebar kepada masyarakat. Hal demikian merupakan salah satu keunggulan berita bergambar dari berita tertulis ${ }^{1}$. Keunggulan film dan berita di televisi lainnya adalah kompleksitas berita yang disampaikan yang mencakup penyampaian verbal dan non-verbal. Bahkan, di era modern ini banyak statiun televisi dan film yang juga mendukung penderita tuna rungu untuk ikut menikmati dan memahami pesan yang disampaikan. Pesan verbal dalam film dan berita bergambar dapat berbentuk narasi, dialog, dan tulisan. Adapun pesan non-verbal lebih berfokus pada karakter, ekspresi, perilaku, penampilan, pencahayaan, warna, sudut pengambilan gambar, music latar, dan tanda lain yang memiliki arti tertentu dalam film tersebut² ${ }^{2}$

Film sebagai media penyampai pesan dan produk budaya populer memiliki dua fungsi utama, sebagai representasi realitas sosial budaya dan sebagai konstruksi realitas. Dalam fungsi yang pertama, film diproduksi untuk menampilkan sisi tertentu (framing) dari realitas yang ada di masyarakat. Para pihak yang terlibat dalam pembuatan film (produser, penulis skenario, dan sutradara) menginginkan terbentuk satu opini bersama setelah para penonton menyaksikan film tersebut. Karenanya, seringkali hal tersebut ditengarai sebagai 'efek samping' dari pesan yang disampaikan melalui media digital berupa film, yaitu hanya menyoroti sesuatu 'yang dianggap' penting oleh pembuatnya ${ }^{3}$.

Fungsi film sebagai representasi dari realitas sosial adalah dalam mengungkap hal-hal yang terlalu sensitif bila dibicarakan dalam obrolan biasa di ruang publik. Isu dan kegelisahan masyarakat yang timbul tidak semuanya dapat dibicarakan dengan leluasa dan netral karena adanya kepentingan dan beberapa pertimbangan yang menyertainya. Karenanya, film sering dipilih menjadi media penyampai pesan

tersebut di samping budaya populer lainnya seperti lagu, mural, lukisan, drama, komik, dan lain sebagainya. Gordon B. Arnold menggambarkan bahwa hubungan yang terbangun antara film sebagai media representasi dan isu yang berada di realitas merupakan hubungan dua arah. Dalam satu hal, film dan budaya populer lainnya merupakan gamabran dan representasi yang nyata dari kehidupan nyata masyarakat.

\footnotetext{
${ }^{1}$ Deepak Nayyar, Modern Mass Communication, First. (Jaipur: Oxford Book Company, 2007), 4

${ }^{2}$ Chatarina Heny Dwi Surwati, "Konstruksi Feminisme Dalam Film Indonesia (Analisis Wacana Kritis Konstruksi Feminisme Dalam Film Indonesia Karya Sutradara Nia Dinata )," Jurnal Komunikasi Massa 1, no. 1 (2012): 3-4.

${ }^{3}$ Nayyar, Modern Mass Communication, 5-6-..
} 
Namun, di lain waktu, visi dan alur cerita di dalam film bisa berubah menjadi media penanam opini yang sedikit banyak mempengaruhi kehidupan di dunia nyata ${ }^{4}$.

Dunia Barat yang didefinisikan meliputi Eropa dan Amerika dan dunia Timur, yang meliputi Afrika dan Asia, meskipun pembagian yang demikian warisan intelektual era kolonial dalam membagi duniaselalu dihantui dengan dikotomi antara keduanya. Dikotomi tersebut pada akhirnya melahirkan strereotyping masing-masing pihak. Masyarakat Timur memiliki pandangan bahwa masyarakat Barat identik dengan negaranegara yang materialistis, sekuler, logis, kapitalis, dan tidak bersifat Teistik dalam memandang segala realitas dalam kehidupan ${ }^{5}$. Pendek kata, dunia Barat adalah wilayah di mana konsep tentang ketuhanan, ilmu dan realitas tidak muncul dalam pandangan hidup beragama ${ }^{6}$.

Hal ini berbeda dengan masyarakat Timur "dianggap" mementingkan kehidupan kerohanian, mistik, pikiran prelogis, keramah-tamahan, dan gotong royong7. Di mata masyarakat Barat, masyarakat Timur dianggap sebagai "dianggap" irrasional, bermoral bejad, kekanak-kanakan, dan "berbeda". Bahkan lebih jauh, tidak sedikit ilmuwan dan pemikir dengan latar belakang budaya Timur yang menyatakan bahwa The Civilization of Capitalism merupakan identitas kultural masyarakat di Eropa dan Amerika. Adapun budaya Katolik atau Protestan di Eropa dan Amerika berada di bawah bayang-bayang kapitalisme ${ }^{8}$.

Film 'God's Not Dead' merupakan film yang diproduksi oleh Pure Flix Entertainment di Amerika Serikat. Film ini mengambil tema kehidupan umat Kristiani dan iman mereka di tengah masyarakat yang dilabeli sebagai negara bebas agama, negara sekuler, dan tidak memiliki tempat untuk hal-hal metafisik seperti keimanan dan ketuhanan. Film ini menunjukkan realitas permasalahan umat Kristiani dalam memperlihatkan identitas keagamaan mereka (dalam konteks ini adalah Kristen) dalam masyarakat Barat. Pemilihan film ini sebagai salah satu representasi kehidupan umat Kristen dalam menunjukkan iman dan kepercayan mereka di negara Barat yang dilabeli 'sekuler'.

Artikel ini akan menganalisis representasi keimanan Kristen di film tersebut . Pisau analisis yang digunakan dalam penelitian ini adalah analisis wacana model Teun A Van Dijk. Yang berfokus pada struktur makro, super struktur, dan struktur mikro dalam suatu film atau karya sastra lainnya. Dengan pendekatan tersebut, pesan-pesan terkait realitas sosial kehidupan umat Kristiani di Amerika dapat ditunjukkan dari tataran makro struktur, super struktur, dan mikro struktur.

\footnotetext{
${ }^{4}$ Gordon. B Arnold, Conspiracy Theory in Film, Television, and Politics (London: Praeger Publishers, 2008), 10.

${ }^{5}$ Hamid Fahmy Zarkasyi, “Worldview Islam Dan Kapitalisme Barat,” Tsaqafah 9, no. 1 (2013): 26.

${ }^{6} \mathrm{Ibid}$.

${ }^{7}$ Koentjaraningrat, Kebudayaan Mentalitas Dan Pembangunan (Jakarta: PT Gramedia, 1981), 132.

8 Zarkasyi, "Worldview Islam Dan Kapitalisme Barat., 16"
} 


\section{Metode Penelitian}

Film merupakan salah satu produk budaya yang seringkali muncul sebagai representasi kehidupan sosial budaya yang berlaku' ${ }^{9}$. Suatu pesan disampaikan melalui film untuk dapat menjangkau penonton dalam jumlah yang banyak dalam waktu yang singkat, hal yang tidak dapat dilakukan oleh media cetak. J. Dudley Andrew mengatakan bahwa film merupakan sebuah media untuk merepresentasikan suatu objek yang diangkat dan tidak bertentangan dengan kenyataan yang berada di luar film ${ }^{10}$. Pesanpesan yang bervariasi, baik berupa verbal maupun non-verbal diharapkan dapat mencapai pemahaman para penonton sesuai dengan tujuan pembuat film. Meskipun tidak dapat dipungkiri pula bahwa storage yang dimiliki para penonton berbeda-beda satu sama lain. Storage yang terlahir dari berbagai pengalaman empiris yang mempengaruhi sudut pandang penonton dalam melakukan resepsi dan representasi ${ }^{11}$. Hal tersebut tentu saja berdampak pada makna yang dihasilkan dalam satu film.

Karenanya, suatu tayangan film seringkali menempatkan penonton untuk merefleksikan berbagai tayangan yang ditonton sesuai dengan storage dan pengalaman yang ada. Pendekatan fenomenologi menempatkan mereka sebagai penyingkap (discoverer) dan bukan pencipta dari representasi film (constructor) tersebut ${ }^{12}$. Dengan kata lain, opini dan pengalaman pribadi penonton akan dipertemukan dengan realitas yang dihadirkan oleh film. Para penonton akan diberi kebebasan menangkap makna yang disampaikan dalam film tersebut, baik verbal maupun non-verbal yang telah disediakan oleh pembuat film. Makna yang dihasilkan kelak adalah hasil dari realitas yang ditangkap dan pengalaman pribadi dari penonton.

Analisis wacana merupakan salah satu upaya dalam memahami wacana yang disampaikan dalam suatu film. Pesan-pesan yang disampaikan dapat berupa makna yang terkandung dalam dialog dan rentetan teks atau terkandung dalam hal lain di luar dialog. Bagian pertama menggunakan pendekatan semantik (logical semantic) dan bagian kedua menggunakan pendekatan pragmatik $^{13}$. Adapun penelitian ini menggunakan pendekatan analisis wacana semantik karena berfokus pada sisi bahasa (linguistik) ${ }^{14}$ dan topik wacana (topic of discourse) atau topik pembicaraan (topic of conversation) yang disajikan dalam film 'God's Not Dead'.

Penelitian berfokus pada dialog dan teks yang terdapat dari film dengan beberapa alasan. Pertama, bahasa bukanlah media komunikasi yang terlepas dari dunia

${ }^{9}$ Ahmad Naufal Dzulfaroh, "Respon Estetis Dalam Adaptasi Novel-Film Al-Ffil Al-Azraq," Leksema 3, no. 2 (2018): 164 .

${ }^{10}$ Allan Casebier, Film and Phenomenology: Toward a Realist Theoy of Cinematic Representation (Cambridge: Cambirdge University Press, 2009), 62.

11 Dzulfaroh, "Respon Estetis Dalam Adaptasi Novel-Film Al-Ffil Al-Azraq."

12 Casebier, Film and Phenomenology: Toward a Realist Theoy of Cinematic Representation, 62.

13 Teun A. van Dijk, Text and Context. Explorations in the Semantics and Pragmatics of Discourse, Longman Griup UK Limited, vol. 63 (Essex: Longman Group UK Limited, 1977).

14 Ibnu Hamad, “Lebih Dekat Dengan Analisis Wacana," Mediator 8, no. 2 (2007): 328. 
nyata. Ia merupakan 'mesin' yang menciptakan dan mengkonstruk dunia sosial ${ }^{15}$. Hal tersebut tidak menunjukkan bahwa realitas tidak nyata. Makna dan representasi adalanya nyata. Objek fisik juga nyata, namun keduanya hanya dapat bertemu melalui pendekatan wacana ${ }^{16}$. Kedua, bahasa merupakan refleksi dari sikap hidup dan tingkah laku. Dari gaya bahasa yang digunakan, penekanan, dan pengulangan, dapat diketahui sisi kekuatan (power), afiliasi (affiliation), daya tarik (attraction), kepentingan (interest), dan rasa tanggungjawab (responsibility) ${ }^{17}$.

Van Dijk membuat kerangka analisis yang tidak hanya menyoroti teks dalam suatu film, namun juga terdiri atas 3 struktur. Keseluruhan struktur tersebut saling mendukung satu sama lain. Struktur tersebut adalah struktur makro, super struktur, dan struktur mikro ${ }^{18}$. Dari ketiga struktur tersebut, ditemukan beberapa hal yang perlu diamati dalam menemukan wacana film ini. Struktur makro berkaitan dengan tematik atau pembicaraan seputar menjelaskan 'Apa yang dikatakan'. Super struktur berkaitan dengan skematik atau topik 'Bagaimana pendapat tersebut disusun?'. Struktur mikro berkaitan dengan beberapa hal seperti semantik (makna dalam teks), sintaksis (bagaimana pendapat disampaikan), stilistik ${ }^{19}$ (pilihan kata apa yang dipakai), dan retoris $^{20}$ (bagaimana dan cara apa penekanan dilakukan).

Dari perangkat wacana tersebut, setiap unit dirinci berdasarkan dimensi operasional analisis wacana. Dimensi tersebut meliputi topik, skema, latar, detail, maksud, bentuk kalimat, koherensi, kata ganti, leksikon, grafis, metafora, dan ekspresi ${ }^{21}$.Dengan demikian, teks komunikasi dalam film tersebut dapat dipahami dengan struktur-struktur yang saling melengkapi dan membawa makna yang utuh.

\section{Barat adalah Negara Sekuler}

Teori ini merupakan sebuah ekspresi pengalaman mayoritas bangsa Timur dalam memandang Barat. Istilah Barat-Timur sendiri merupakan warisan era kolonialisme dan komunisme. Dikotomi tidaklah berdasarkan letak geografis, namun lebih kepada alasan kebudayaan (cultural). Karenanya, negara-negara Islam dianggap sebagai Timur meskipun membentang dari Afrika Utara hingga Indonesia dan Australia tetap dianggap sebagai Barat ${ }^{22}$.

\footnotetext{
${ }^{15}$ Marianne Jorgensen and Louise J Phillips, Discourse Analysis as Theory and Method (London: SAGE Publications Ltd, 2002), 3-4 ; Hamad, "Lebih Dekat Dengan Analisis Wacana, 336."

16 Jorgensen and Phillips, Discourse Analysis as Theory and Method, 9.

17 Ronald N Adler and George Rodman, Understanding Human Communication, Ninth Edit. (New York: Oxford University Press, 2006), 85-88.

${ }^{18}$ Alex Sobur, Analisis Teks Media (Bandung: Rosda Karya, 2001), 74.

19 Ibid, 12.

20 Ibid, 13.

21 Imam Fauzi, “Pesan Dakwah Melalui Film (Analisis Wacana Film Do'a Yang Mengancam)” (IAIN Sunan Ampel, 2009), 68.

22 Stjepan G Mestrovic, The Balkanization of the West: The Confluence of Postmodernism and Postcommunism (London: Routledge, 2005), 68.
} 
Dalam era selanjutnya, sebagai efek dari dikotomi tersebut, tulisan dan diskusi ilmiah tetap hidup dalam makna Barat dan Timur. Perbedaan yang kontras antara keduanya masih sering terlihat hingga saat ini. Budaya dan masyarakat Timur "dianggap" mementingkan kehidupan kerohanian, keramah-tamahan, gotong royong, mistik, serta pikiran prelogis. Adapun masyarakat Barat (Eropa dan Amerika) lebih mementingkan pikiran tentang materialisme (kebendaan), individualisme, pikiran logis, serta hubungan asasguna (hanya berdasar pada prinsip guna) ${ }^{23}$.

Dalam ranah pemikiran dan hubungan antar agama, pandangan hidup Barat berbasis materialisme, pragmatisme, filsafat sekuler, dan berujung pada pemusnahan ajaran agama ${ }^{24}$.Identitas kebudayaan Barat juga tidak berdasar pada ajaran agama, baik Katolik maupun Protestan, melainkan pada semangat kapitalisme ${ }^{25}$. Pendek kata, ideologi dan peradaban Barat 'dianggap' selalu menyingkirkan segala hal metafisik, termasuk agama dan Tuhan dalam aspek negara, pendidikan, moralitas, dan segala aspek kehidupan ${ }^{26}$.

Ideologi tersebut lahir dari upaya modernisasi yang lahir setelah era Pencerahan (Enlighment/Aufklarung) di Barat. Pasca masa kegelapan (Dark Age), gerakan tersebut bertujuan membebaskan umat dari ikatan tradisi, khususnya tradisi gereja dengan bantuan akal dan pengetahuan. Gerakan tersebut yang secara tidak langsung menciptakan masyarakat sekuler yang membuang pengaruh agama ke tempat berdimensi pribadi karena manfaat yang tidak benar-benar mereka rasakan ${ }^{27}$.

Berbagai alasan tersebut mendasari stigma negatif kehidupan tanpa Tuhan di Barat. Melalui film 'God's Not Dead', pembuat film seolah menyuarakan kepada dunia bahwa Tuhan 'masih' ada dan bertahta di hati orang-orang beriman. Sekulerisme yang seringkali dituduhkan kepada seluruh masyarakat Barat nyatanya tidak sepenuhnya benar. Karenanya, penulis mencoba menangkap wacana tersebut.

\section{Hasil dan Pembahasan}

\section{Isi Film}

Film pertama God's Not Dead dirilis tahun 2014. Film tersebut disutradarai oleh Harold Cronk. Film tersebut pertama kali tayang di layar bioskop pada 21 Maret 2014 oleh Pure Flix Entertainment yang berkantor pusat di Arizona, Amerika Serikat. S Cary Solomon dan Chuck Konzelman menjali penulis skenario berdasarkan pada buku

\footnotetext{
${ }^{23}$ Koentjaraningrat, Kebudayaan Mentalitas Dan Pembangunan, 132.

${ }^{24}$ Mujahid Imaduddin, "Dampak Liberalisasi Pemikiran Islam Terhadap Kehidupan Sosial," Kalimah 15, no. 1 (2017): 107.

25 Zarkasyi, "Worldview Islam Dan Kapitalisme Barat, 16"

${ }^{26}$ Ahmad Khoirul Fata and Siti Mahmudah Noorhayati, "Sekularisme Dan Tantangan Pemikiran Islam Kontemporer," Madania 20, no. 2 (2016): 219.

${ }^{27}$ Akhmad Djatmiko, "Kebangkitan Agama Dan Prasangka Sekuler Dalam Kajian Hubungan Internasional," Politika: Jurnal Ilmu Politik 8, no. 1 (2017): 5-18.
} 
berjudul God's Not Dead: Evidence for God in an Age of Uncertainty karya Rice Broock. Film ini berhasil meraup pendapatan sebanyak lebih dari 64 juta dolar dengan biaya produksi yang hanya memakan biaya 2 juta dolar. Pada akhir tahun 2014, film ini menempati peringkat ke-93 untuk film dengan pendapatan kotor terbesar di dunia 28 .

Film pertama ini berfokus pada diskusi alot antara seorang mahasiswa baru, Josh Wheaton (Shane Harper) dengan seorang dosen di kelas filsafatnya, Professor Radisson (Kevin Sorbo) terkait eksistensi Tuhan dari kacamata ilmu pengetahuan dan filsafat. Sang Professor bersikukuh dan mengajak seluruh peserta kelasnya untuk menyetujui ketiadaan Tuhan di dunia. Josh Wheaton yang merupakan seorang Kristen yang taat tidak sependapat dengan dosennya dan menerima tantangan dosennya untuk menjelaskan antitesis bahwa Tuhan tidak mati demi mendapatkan predikat lulus di kelas tersebut.

Diskusi tersebut membawa dampak kepada kehidupan keduanya. Josh Wheaton harus merelakan ditinggalkan kekasihnya, Amy (Trisha LaFache) karena bersikukuh menerima tantangan Professor Radisson. Di sisi lain, Prof. Radisson juga sedang mengalami keretakan dalam rumah tangganya, di mana istrinya Mina (Cory Oliver) adalah seorang Kristen yang taat dan ingin agar suaminya mengikuti langkahnya.

Dalam rangka mencari pencerahan, keduanya sering berinteraksi dengan Pendeta Dave (David A.R. White) dan Pendeta Jude (Benjamin Onyango). Selain permasalahan tersebut, ada pula Martin Yip (Paul Kwo) dan Ayisha (Hadeel Sittu) yang sering berkonsultasi dengan Pendeta Dave karena agama Kristen lebih cocok dengan hati mereka dibandingkan keyakinan mereka saat itu. Keduanya juga mendapatkan pencerahan saat melihat bagaimana diskusi antara Josh Wheaton dan Prof. Radisson berlangsung.

Singkat cerita, film tersebut diakhiri dengan pengakuan kekalahan Prof. Radisson dari argument-argumen yang disampaikan oleh Josh Wheaton. Berbagai fakta ilmiah dan pendapat ilmuwan terkemuka nyatanya mendukung keberadaan Tuhan dan menangkal bahwa Tuhan telah mati. Kebencian Prof. Radisson terkait keberadaan Tuhan ternyata memiliki alasan pribadi terkait pengalaman buruknya di masa lampau.

Kesuksesan film tersebut dilanjutkan dalam sekuelnya, God's Not Dead 2 yang dirilis tahun 2016. Film tersebut masih disutradarai oleh Harold Cronk. Film yang dirilis pada 1 April 2016 ini juga mengikuti kesuksesan pendahulunya dengan meraup pendapatan sebanyak 24 juta dolar dari biaya produksi sebesar 5 juta dolar.

Film ini berfokus pada kisah seorang guru SMA, Grace Wesley (Melissa Joan Hart) yang mengajar sejarah dunia. Masalah muncul ketika seorang siswanya, Brooke Thawley (Hayley Orrantia) bertanya tentang posisi Yesus sebagai tokoh yang berpengaruh dalam sejarah dunia. Pihak sekolah dan orangtua Brooke menggugat Grace karena

28 “2014 Worldwide Grosses," Box Office Mojo, last modified 2014, accessed December 12, 2020, https://www.boxofficemojo.com/yearly/chart/?view2=worldwide\&yr=2014. 
membicarakan Tuhan di ruang publik, yaitu di kelas. Karena Grace tak jua mencabut pernyataannya, ia harus menghadapi persidangan. Dalam persidangan tersebut, ia dibantu oleh seorang pengacara muda Tom Endler (Jesse Metcalfe).

Dalam film ini, Pendeta Dave (David A.R. White) hadir di persidangan sebagai salah seorang juri. Selain dia, masih ada beberapa pemain di film pertama yang turut hadir di film ini seperti Pendeta Jude, Martin Yip, dan Amy.

Di akhir film, dikisahkan bahwa Grace dan pengacaranya, Tom Endler berhasil memenangkan gugatan. Berbagai fakta sejarah, logika, dan argumen disampaikan dalam rangka menegaskan bahwa Yesus merupakan tokoh sejarah yang tak dapat disangkal. MembawaNya ke dalam ruang kelas adalah sebuah tindakan yang tidak keluar dari koridor yang ilmiah.

Film ketiga adalah God's Not Dead: A Light in Darkness yang dirilis pada 30 Maret 2018. Film ini disutradari oleh Michael Manson dan dibintangi oleh para pemeran di film pertama dan kedua seperti David A.R. White, John Corbett, Shane Harper, dan Benjamin Onyango. Film ini hanya mampu meraih 2,6 juta dolar dan menempati peringkat ke-12 pada akhir minggu perdana sekaligus menjadi seri dengan pendapatan terendah dibandingkan kedua film terdahulu.

Film ini berfokus pada pribadi Pendeta Dave (David A.R. White) yang sedang dirundung banyak pergumulan hebat. Ia harus mendekam di penjara beberapa saat karena menolak menyerahkan teks khotbahnya kepada pihak yang berwajib. Selepas itu, ia mendapati bahwa pihak sekolah meminta lokasi gerejanya dipindah karena akan diadakan perluasan gedung sekolah. Pada suatu malam, ia harus menerima kenyataan bahwa ada percobaan pembakaran gereja tersebut yang mengakibatkan kerusakan yang parah dan wafatnya Pendeta Jude di depan matanya. Rentetan kejadian tersebut membuat Pendeta Dave harus menghubungi kakaknya yang juga seorang pengacara, Pearce Hill (John Corbett) yang tidak percaya dengan kebenaran Iman Kristen.

Di akhir film, Pendeta Dave yang mulai kehilangan arah dan kesabaran mulai menemukan titik cerah. Adalah Pendeta Roland Dial (Greg Alan Williams) yang menasehatinya dengan berbagai sikap, tingkah laku, dan perangai yang dicontohkan oleh Yesus dalam hidupNya. Selain itu, Josh Wheaton juga sering mengingatkan berbagai nasehat yang dahulu pernah diberikan oleh Pendeta Dave. Pendeta Dave akhirnya memutuskan untuk memaafkan pelaku pembakaran gerejanya dan memutuskan untuk menarik gugatannya terhadap pihak sekolah dengan menyerahkan lokasi gerejanya digunakan untuk keperluan sekolah. Ia pun mengajak para jemaatnya untuk membangun gereja di lokasi yang baru yang bernama "Gereja St. Jude" sebagai monumen pengingat akan perjuangan dan pengorbanan Pendeta Jude. Sikap inilah yang akhirnya membawa kakaknya, Pearce Hill menemukan jawaban atas ketidakpercayaannya akan kehadiran Tuhan dan karyaNya dalam hidupnya. 


\section{Analisis Wacana Film God's Not Dead}

Dalam memahami pesan komunikasi dan wacana yang dibangun di film tersebut, peneliti menggunakan model analisis wacana Teun A. Van Dijk. Dalam usaha memahami sebuah wacana, Van Dijk menggunakan enam unsur, yaitu segi tematik, segi skematik, segi semantik, segi sintaksis, segi stilistik, dan segi retoris. Berikut adalah beberapa analisa percakapan di fim tersebut.

\section{Struktur Tematik}

Struktur ini merupakan struktur makro wacana dalam sebuah film. Ketiga film tersebut mengangkat tema yang sama, yaitu masalah keimanan penganut Kristen dalam kehidupan di negara Barat. Masing-masing film memiliki fokus yang berbeda-beda. Di film pertama, tema yang diangkat adalah kedudukan agama dan ilmu pengetahuan. Bagaimanapun seorang ilmuwan dan suatu ilmu mengingkari eksistensi Tuhan, fakta ilmiah yang rasional akan selalu mengarah pada pengakuan keberadaan Tuhan.

Dalam film kedua, tema yang diangkat adalah kebebasan berbicara tentang agama di ruang publik dan hubungan antara Yesus dengan sejarah. Banyak yang meyakini bahwa Yesus hanyalah sekedar khayalan umat Kristiani dan Dia tidak pernah eksis di kehidupan ini. Berbicara tentang Yesus berarti berbicara tentang mitos dan takhayul. Dalam film ini, keyakinan tersebut ditentang dengan menggunakan berbagai fakta sejarah bahwa Yesus adalah nyata dan termasuk tokoh yang berpengaruh dalam rentetan perjalanan dunia.

Kedua pesan yang ingin disampaikan di kedua film tersebut adalah agama tidak bertentangan dengan ilmu pengetahuan dan sejarah. Kedua hal tersebut adalah pembicaraan yang sering dihubung-hubungkan dengan pandangan sekuler. Sesuai sejarah lahirnya, sekulerisme sendiri memang sebuah upaya memisahkan agama dari berbagai segi kehidupan manusia, termasuk ilmu pengetahuan dan sejarah. Melalui kedua film tersebut, pesan bahwa agama dapat berjalan berdampingan dengan ilmu pengetahuan dan sejarah terasa kuat. Dengan kata lain, ketika seseorang ingin memperdalam ilmu pengetahuan dan sejarah, ia tidak perlu menanggalkan keimanan yang ia miliki.

Di film ketiga, tema yang diangkat lebih mendasar, yaitu bagaimana bersikap sebagaimana yang diajarkan Yesus. Di sini Pendeta Dave digambarkan sebagai seorang pendeta yang selalu dekat dengan Tuhan dan memberikan khotbah keagamaan kepada jema'atnya. Namun ia tetap manusia biasa yang seringkali merasa bangga secara berlebih dan merasa berhak untuk membenci mereka yang berbuat jahat kepadanya. Hingga di akhir film, Pendeta tersebut menemukan pesan-pesan kebaikan Yesus yang kadangkala ia lupakan. 


\section{Struktur Skematik}

Struktur yang dimaksud di sini adalah tentang bagaimana susunan teks wacana dan alurnya diproduksi. Susunan sebuah teks wacana terdiri dari pendahuluan, isi wacana, dan penutup. Selain itu, bagaimana summary dan story yang mendukung tema wacana juga menjadi fokus dalam struktur skematik. Struktur ini merupakan superstruktur yang menggambarkan bentuk umum dari suatu teks dalm film ini. Dalam analisisnya, judul film tersebut "God's Not Dead" merupakan sebuah pernyataan dan jawaban bagi mereka yang masih ragu akan keberadaan Tuhan dan karyaNya di dunia ini.

Beberapa dialog yang membawa wacana sebagaimana yang tertera dalam judul film antara lain dialog antara Martin Yip dan ayahnya via telepon:

Martin Yip berkata, "Aku sudah lulus beberapa mata kuliah, termasuk matematika dan kimia. Tapi salah satu mata kuliah pilihanku, perkenalan filsafat, banyak membahas Tuhan".

Ayahnya berkata dengan wajah cemas, “Tuhan? Kenapa membahas Tuhan?”.

Martin pun menjawab, "Ada banyak pendapat yang menyatakan keberadaanNya".

Ayahnya bertanya lagi, "Apa pendapat profesormu?".

Martin menanggapi, "Dia sangat yakin bahwa Tuhan tidak ada".

Ayahnya pun menimpali seraya mengakhiri perbincangan, "Berarti itu tidak jadi masalah, Tuhan tidak ada. Ayah sedang sibuk, ayah harus bekerja". (God's Not Dead 1)

Contoh lainnya dapat terlihat saat Profesor Radisson berargumen tentang agama di suatu sesi diskusi: "Karena agama itu, seperti virus pikiran yang ditinggalkan orang tua bagi anak mereka, dan kekristenan adalah virus terburuk di dunia ini. Perlahan-lahan merayap ke dalam hidup kita saat kita lemah atau sakit atau tak berdaya". Josh Wheaton menanggapi, "Jadi, agama itu seperti penyakit?". Profesor Radisson menjawab," Ya. Benar, menginfeksi segalanya". (God's Not Dead 1)

Dalam film God's Not Dead 2, ada adegan Jaksa penuntut membuka tuntutan di pengadilan dengan berkata:"Penggugat adalah orang tua dari seorang siswa di kelas Nona Wesley yang menjadi sasaran persidangan ajaran Yesus Kristus yang dibandingkan dengan baik dengan ajaran Mahatma Gandhi. Kita semua tahu bahwa Yesus adalah bagian dari tradisi agama tertentu. Orang tua ini, yang berusaha untuk meningkatkan putrid mereka untuk menjadi seorang pemikir yang bebas, bebas dari dogma agama apapun, yang sepenuhnya tersinggung dengan apa yang terjadi di kelas itu". (God's Not Dead 2). Dialog-dialog tersebut menunjukkan beberapa pertanyaan dan sanggahan terkait keberadaan Tuhan yang menjadi fokus masalah di dalam film dan dijawab dengan tegas melalui judul dan isi film tersebut. 


\section{Struktur Semantik}

Dalam struktur ini, analisis berfokus pada makna yang ditekankan dalam sebuah teks. Elemen ini membahasa tentang hubungan antar kalimat yang menunjukkan makna tertentu dalam suatu bangunan wacana yang utuh.

Dalam salah satu adegan, setelah mendengarkan khotbah Pendeta Roland Dial tentang pentingnya cinta kasih dalam melakukan berbagai ritual ibadah dan menjalani kehidupan, Pendeta Dave mencoba merenungkan isi khotbah tersebut. Keesokan harinya, ia mendapat pesan singkat dari nomor yang tak dikenal yang mengatakan bahwa Adam Richertson adalah pelaku pembakaran gereja yang menyebabkan Pendeta Jude meninggal. Ia pun segera mendatangi Adam dan meluapkan emosinya kepadanya. Terakhir, ia menjebloskan Adam ke penjara karena kelakuannya. Dalam adegan ini, terdapat kontradiksi dari ajaran yang didapatkan oleh Pendeta Dave dengan tindakan yang diambil setelahnya. Hal ini menunjukkan makna yang berlawanan antara perkataan dan tingkah laku.

Struktur semantik lainnya dapat terlihat dalam dialog Pendeta Dave dan Pendeta Roland. Setelah melewati banyak masalah, Pendeta Dave bertemu dengan Pendeta Roland Dial lagi. Pendeta Roland bertanya: "Bagaimana kabarmu?". Pendeta Dave menjawab: "Aku baik-baik saja". Lalu pendeta Roland berkata lagi: "Kau yakin kau baikbaik saja setelah banyak hal yang terjadi di televisi dan persengketaanmu dengan Tom Ellsworth dan sekarang dengan anak ini?". Pendeta Dave mencoba berkilah: "Aku tidak meminta semua perseteruan ini". Pendeta Roland kembali menasehatinya: "Tapi itulah kenyataannya. Kau harus berfokus pada apa yang penting. Orang-orang banyak tertarik dengan Yesus karena cinta kasihNya, kebaikanNya, dan kesabaranNya. Dia selalu menyampaikan kebenaran tanpa menjatuhkan dirinya dalam posisi tawar-menawar. Dia selalu bersikap lembut kepada mereka yang lemah dan keras kepada mereka yang arogan. Ketika Ia berbicara dengan orang bodoh, Ia bersabar dan tidak pernah menjadikan dirinya termasuk orang bodoh. Ia juga tidak pernah merasa bangga diri, David". (God's Not Dead 3). Dalam dialog tersebut juga menunjukkan hubungan kalimat dalam perbincangan keduanya. Jawaban "baik-baik saja” dari Pendeta Dave justru bermakna sebaliknya dan diikuti nasehat dari Pendeta Roland tentang apa yang harus ia lakukan saat sedang tidak baik-baik saja.

\section{Struktur Sintaksis}

Aspek yang dianalisa dalam struktur ini adalah penggunaan bentuk kalimat koherensi dan penggunaan kata ganti. Elemen bentuk kalimat dan koherensi dititiktekankan pada suatu pertalian atau kalimat berbentuk kata. Koherensi adalah pautan antar gagasan yang menyusun sebuah wacana. 
Di antara struktur sintaksis di dalam film tersebut adalah dialog Pendeta Dave dan Pendeta Roland. Setelah mendapatkan nasehat dari Pendeta Roland, Pendeta Dave berkata: "Ini tidak ada hubungannya dengan rasa bangga, Roland. Dan tanpa bermaksud menyinggung, mungkin kau akan sedikit lebih mengerti bila kau yang menjadi korban penyerangan". Pendeta Roland menanggapinya: "Saudaraku, kau pikir dengan siapa kau berbicara? Aku adalah pengkhotbah berkulit hitam di negara bagian Deep South. Aku dapat membangunkan sebuah gereja untukmu dengan semua batu bata yang dilemparkan kepadaku melalui jendela rumahku". Pendeta Dave: Kau benar, aku minta maaf'. (God's Not Dead 3). Dalam dialog ini Pendeta Dave menempatkan diri sebagai korban dan tidak berhak menerima nasihat dari orang yang tidak ikut merasakannya. Sanggahan tersebut dibalas oleh kalimat yang berisi pengalaman Pendeta Roland sebagai tautan dari nasihat yang diberikan di awal.

Dialog di ruang kelas juga menunjukkan adanya struktur sintaksis yang menunjukkan pada iman Kristen. Dalam akhir diskusi, Josh Wheaton bertanya kepada Prof. Radisson: "Siapa sebenarnya yang ingin anda buat gagal, Profesor? Aku atau Tuhan?". Setelah suasana hening sepersekian detik, Josh Wheaton bertanya lagi: "Apa anda membenci Tuhan?". Prof. Radisson menjawab: "Itu bukan lagi pertanyaan". Josh mengulangi: "Baiklah, mengapa anda membenci Tuhan? Tolong jawab pertanyaannya! Anda tahu ilmu pengetahuan dan segala argumen. Ilmu pengetahuan mendukung keberadaanNya. Anda tahu kebenaran itu. Lalu, mengapa anda membenci Dia? Mengapa?". Prof. Radisson menjawab dengan penuh emosi: "Karena Ia telah mengambil segalanya dariku. Benar, aku membenci Tuhan. Hanya rasa benci yang aku punya". Josh Wheaton menutup diskusi dengan pertanyaan menohok:"Bagaimana bisa anda membenci seseorang jika orang itu tidak ada?" (God's Not Dead 1)

Dalam dialog kedua, kata ganti orang pertama disandingkan dengan kata ganti orang ketiga. Tuhan diekspresikan dengan kata ganti orang ketiga yang menunjukkan sikap kedekatan dan keakraban. Dalam dialog sebelumnya, Tuhan diekspresikan dengan sebutan Tuhan. Saat dialog semakin meruncing, keduanya menggunakan kata ganti orang ketiga tunggal.

\section{Struktur Stilistik}

Aspek yang ditekankan dalam elemen ini adalah pilihan kata yang digunakan untuk mengkonstruksi wacana. Analisis difokuskan pada gaya bahasa yang digunakan oleh penulis atau pembicara untuk menyampaikan maksudnya.

Di antara gaya bahasa yang digunakan adalah obrolan Pendeta Jude dengan Pendeta Dave. Pendeta Jude berkata kepada Pendeta Dave dengan sedikit sindiran dan juga motivasi ketika mobil mereka mogok sejak pagi: "David, kita sudah habiskan seluruh hidup kita membahas tentang iman. Sekarang aku memintamu menunjukkan iman itu". Ia 
menjawab: "Baiklah" dan mencoba menyalakan mobilnya. Setelah mobil tersebut dapat menyala, Dave berkata: "Mustahil". Jude segera membantahnya dan berkata: "Bukan. Iman" (God's Not Dead 1). Gaya bahasa ironi muncul di dalam dialog ini. Yaitu saat seorang Pendeta yang sering membicarakan iman justru perlu diminta untuk menunjukkan dan mempercayai bahwa yang terjadi adalah hasil dari sebuah keimanan.

Gaya bahasa lain juga digunakan saat adegan pembelaan di ruang sidang dalam film God's not Dead 2. Berikut adalah pembelaan terakhir Tom Endler terhadap Grace Wesley: "Aku kataan dia tidak bersalah dari semua kesalahan. Tapi aku meminta anggota juri untuk menemukan supaya melawan dirinya juga. Maksudku, mari kita hadapi itu. Dia memiliki keberanian untuk percaya tidak hanya bahwa ada satu Tuhan, tapi dia memiliki sebuah hubungan pribadi dengan Dia, yang mana hubungan itu mewarnai semua yang dikatakannya dan dilakukannya. Aku pikir sudah waktunya kita berhenti berpura-pura bahwa kita bisa mempercayai seseorang seperti ini untuk dilayani di dalam kapasitas public. Di dalam nama toleransi dan keragaman, aku katakana kita menghancurkan dia. Kemudian kita semua bisa pergi ke isi kuburan kita, untuk mengetahui kita telah menginjak keluar percika iman yang terakhir yang tidak pernah dipamerkan di khalayak umum".

Ia menambahkan: "Aku hanya berkata bahwa semua proses ini adalah sebuah bentuk penghinaan. Jika kita akan bersikeras bahwa hak orang Kristen untuk percaya ditempatkan lebih rendah dari semua hak-hak yang lain, maka itu bukan sebuah hak. Seseorang akan selalu merasa tersinggung". Dialog ini sejatinya digunakan untuk membela seseorang dalam menyuarakan dan menunjukkan keimanananya di ruang publik dan bukan sebaliknya sebagaimana yang dituduhkan kepada mereka.

\section{Struktur Retoris}

Struktur ini berfokus pada bagaimana dan dengan cara apa penekanan dilakukan. Retoris juga berarti kalimat pertanyaan yang tidak memerlukan suatu jawaban. Di dalam film ini ditemukan banyak struktur retoris yang berupa pertanyaan sebagai penekanan atas informasi dan argumen yang tak terbantahkan.

Di antara contoh dialoh tersebut adalah ketika Josh Wheaton menutup diskusi dengan pertanyaan menohok kepada Prof. Radisson:"Bagaimana bisa anda membenci seseorang jika orang itu tidak ada?" (God's Not Dead 1). Contoh lainnya juga muncul dalam sebuah wawanca di televisi, sang pembawa acara bertanya: "Apakah kau percaya bahwa dia berkhotbah kepada murid-muridnya?". Ia menjawab: “Gubernur, tidak sama sekali. Yesus Krsitus adalah orang yang paling berpengaruh yang pernah hidup. Bagaimana kamu bisa mengabaikan kebenaran itu dan tidak mengajar sejarahNya?". (God's Not Dead 2)

Dialog antar Pendeta dan kerabatnya juga beberapa kali menggunakan struktur ini. Saat Pendeta Dave berbicara kepada kakaknya Pearce Hill: "Apakah anda percaya 
pada apa yang sedang kita perjuangkan?". Kakaknya menjawab: “Apakah aku percaya pada hakmu untuk menjaga gerejamu? Jawabannya iya. Tapi selebihnya, kau sudah tahu jawabannya". Pendeta Dave bertanya lagi: "Lantas untuk apa kau menolongku?". Kakaknya menjawab: "Apa yang kamu pikir aku lakukan untuk mencari nafkah?". Pendeta Dave menutup dengan pertanyaan: "Jadi, apakah agama tidak memiliki nilai kecuali hukum yang melindunginya?". (God's Not Dead 3)

Ketiga dialog tersebut merupakan pertanyaan yang tidak membutuhkan jawaban. Hal ini merupakan hal-hal penting yang menjadi argumen dari pertanyaan atau pernyataan tentang eksistensi Tuhan. Pertanyaan kunci tersebut digunakan sebagai inti dari setiap episode film yang ada sesuai dengan konteks permasalahan masing-masing film.

\section{Representasi Iman Kristen di Film God's Not Dead}

Berbagai dialog di atas menghadirkan representasi bahwa Iman Kristen masih hidup dan berkembang di Eropa dan Amerika. Berbagai persepsi yang menggeneralisir bahwa Barat (Eropa dan Amerika) adalah sekuler, bersandar pada semanagat kapitalisme dan meninggalkan semangat Katolik dan Protestan nyatanya tidak sepenuhnya benar. Di negara-negara Barat, iman seorang Kristen masih diterima dan bertahan di ruang publik, tidak seperti yang selama ini dituduhkan.

Film God's Not Dead merupakan sebuah representasi keimanan Kristen di negara Barat, yaitu Eropa dan Amerika. Film adalah sebuah representasi dari realita sosial budaya yang mungkin tidak diketahui banyak orang. Isi film sendiri adalah rekaman dari realitas yang tumbuh dan berkembang di masyarakat dan kemudian diproyeksikan ke dalam bentuk audio dan visual. Film tidak terlepas dari realitas yang ada di kehidupan nyata. Sebagaimana film ini, merupakan jawaban bagi mereka yang menganggap Tuhan telah mati di negara-negara Barat dan juga sebagai penguat iman bagi umat Kristen bahwa keimanan mereka tak lekang oleh waktu, tidak bertentangan dengan ilmu pengetahuan maupun fakta empiris. Bahkan, pesan lebih jauh yang ingin disampaikan melalui film ketiga adalah betapapun seorang umat Kristen menghadirkan iman dalam kehidupan mereka, bila tanpa dibarengi rasa cinta kasih sesama makhluk dan manusia, rasa rendah diri, dan rasa saling menghargai tidaklah berarti apa-apa. Tindakan nyata mereka dalam moralitas, sikap, dan perilaku jauh lebih penting di kehidupan ini dan juga merupakan sebuah lompatan dari iman yang ada di dalam dada.

\section{Kesimpulan}

Penelitian ini menunjukkan bahwa penulis skenario dan sutradara film tersebut ingin menyampaikan bahwa beragama di Barat adalah sah-sah saja. Meskipun ada beberapa kesulitan yang dihadapi, namun iman Kristen tetap bisa bertahan di sana. 
Panggilan nurani manusia untuk beragama dan bertuhan adalah sebuah kewajaran, tanpa memandang kondisi sosial masyarakat yang berada di tempat tersebut.

Setelah banyaknya pendapat terkait sekulerisme di Eropa dan Amerika, film ini menjadi antitesis dari ketiadaan Tuhan dan agama di Barat. Melalui film ini realitas yang sering tertutupi oleh berbagai stigma buruk dan stereotyping di Barat dimunculkan. Peneliti mencoba memahami pesan dan wacana tersebut dengan analisis wacana model Van Dijk.

Hasil analisis di atas menunjukkan bahwa mulai dari tataran struktur makro, super struktur, hingga struktur mikro, semuanya membentuk satu alur dan satu wacana. Wacana tersebut menggiring opini penonton yang beragama Kristen untuk semakin memperkuat keimanan mereka. Audio, visual, dan bahasa verbal yang disajikan juga mengarah pada satu wacana tersebut. Adapun bagi penonton yang non Kristen dan bukan dari Eropa dan Amerika, film tersebut menjadi narasi tandingan (counter narrative) terkait isu sekulerisme di negara-negara Barat.

\section{Referensi}

Adler, Ronald N, and George Rodman. Understanding Human Communication. Ninth Edit. New York: Oxford University Press, 2006.

Arnold, Gordon. B. Conspiracy Theory in Film, Television, and Politics. London: Praeger Publishers, 2008.

Casebier, Allan. Film and Phenomenology: Toward a Realist Theoy of Cinematic Representation. Cambridge: Cambirdge University Press, 2009.

van Dijk, Teun A. Text and Context. Explorations in the Semantics and Pragmatics of Discourse. Longman Griup UK Limited. Vol. 63. Essex: Longman Group UK Limited, 1977.

Djatmiko, Akhmad. “Kebangkitan Agama Dan Prasangka Sekuler Dalam Kajian Hubungan Internasional.” Politika: Jurnal Ilmu Politik 8, no. 1 (2017): 5-18.

Dzulfaroh, Ahmad Naufal. "Respon Estetis Dalam Adaptasi Novel-Film Al-Ffil Al-Azraq." Leksema 3, no. 2 (2018): 157-168.

Fata, Ahmad Khoirul, and Siti Mahmudah Noorhayati. "Sekularisme Dan Tantangan Pemikiran Islam Kontemporer." Madania 20, no. 2 (2016): 215-228.

Fauzi, Imam. "Pesan Dakwah Melalui Film (Analisis Wacana Film Do'a Yang Mengancam).” IAIN Sunan Ampel, 2009.

Hamad, Ibnu. "Lebih Dekat Dengan Analisis Wacana." Mediator 8, no. 2 (2007): 325-344. Imaduddin, Mujahid. "Dampak Liberalisasi Pemikiran Islam Terhadap Kehidupan Sosial.” Kalimah 15, no. 1 (2017): 91-116.

Jorgensen, Marianne, and Louise J Phillips. Discourse Analysis as Theory and Method. London: SAGE Publications Ltd, 2002.

Koentjaraningrat. Kebudayaan Mentalitas Dan Pembangunan. Jakarta: PT Gramedia, 1981.

Mestrovic, Stjepan G. The Balkanization of the West: The Confluence of Postmodernism and Postcommunism. London: Routledge, 2005.

Nayyar, Deepak. Modern Mass Communication. First. Jaipur: Oxford Book Company, 2007.

Sobur, Alex. Analisis Teks Media. Bandung: Rosda Karya, 2001. 
Surwati, Chatarina Heny Dwi. "Konstruksi Feminisme Dalam Film Indonesia ( Analisis Wacana Kritis Konstruksi Feminisme Dalam Film Indonesia Karya Sutradara Nia Dinata )." Jurnal Komunikasi Massa 1, no. 1 (2012): 1-24.

Zarkasyi, Hamid Fahmy. "Worldview Islam Dan Kapitalisme Barat." Tsaqafah 9, no. 1 (2013): 15-37.

“2014 Worldwide Grosses.” Box Office Mojo. Last modified 2014. Accessed December 12, 2020.

https://www.boxofficemojo.com/yearly/chart/?view2=worldwide\&yr=2014. 